\title{
A most effective method for selecting a broad range of short and medium- chain-length polyhidroxyalcanoate producing microorganisms
}

\author{
Dolly Margot Revelo Romo \\ Bioprocesses and Bioprospecting Group \\ Instituto de Biotecnología de la Universidad Nacional \\ Ciudad Universitaria, Edificio Manuel Ancizar \\ Bogotá, Colombia \\ Tel: 571316 5000. Ext 16970/71 \\ Fax: 5713165415 \\ E-mail: dmrevelor@unal.edu.co \\ María Victoria Grosso \\ Bioprocesses and Bioprospecting Group \\ Instituto de Biotecnología de la Universidad Nacional \\ Ciudad Universitaria, Edificio Manuel Ancizar \\ Bogotá, Colombia \\ Tel: 571316 5000. Ext 16970/71 \\ Fax: 5713165415 \\ E-mail:mvgrossob@unal.edu.co
Nubia Carmenza Moreno Solano
Bioprocesses and Bioprospecting Group
Ciudad Universitaria, Edificio Manuel Ancizar Bogotá, Colombia
Tel: 571316 5000. Ext 16972
Fax: 5713165415
E-mail: ncmorenos@unal.edu.co \\ Instituto de Biotecnología de la Universidad Nacional \\ Dolly Montoya Castaño* \\ Bioprocesses and Bioprospecting Group \\ Instituto de Biotecnología de la Universidad Nacional \\ Ciudad Universitaria, Edificio Manuel Ancizar \\ Bogotá, Colombia \\ Tel: 571316 5000. Ext 16951/52/54 \\ Fax: 5713165415 \\ E-mail: dmontoyac@unal.edu.co
}

Financial support: This research formed part of a project financed by COLCIENCIAS (Instituto Colombiano Francisco José de Caldas) (project 1101-1212388).

Keywords: 16S rDNA, colony PCR, degenerate primers, PHA synthase, polyhydroxyalcanoate, seminested PCR.

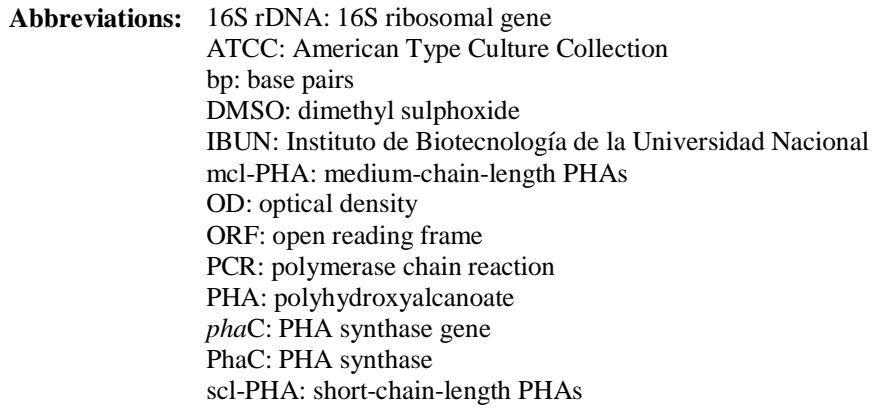

*Corresponding author 
A molecular approach was used for selecting polyhydroxyalcanoate (PHA)-accumulating potential Gram-negative bacteria from different genera by colony polymerase chain reaction (PCR). Three degenerate primers were designed for amplifying a fragment from PHA synthase gene (phaC) (Class I), phaC1 and phaC2 (Class II) genes for detecting PHA-producing bacteria. Thirty-four out of 55 bacterial strains from the old collection selected using Sudan black B staining were phaC+. PCR was used for directly selecting 35 new collection bacterial strains; these strains were phaC+ and their ability to produce PHA was confirmed by Sudan black B staining. Four specific primers were designed on genes of Class II PHA biosynthesis operon. These primers were used for evaluating 9 strains from the old phaC+ collection; 6 showed Class II PHA synthase organisation. 34 from the old and new bacterial isolation were characterised by $16 \mathrm{~S}$ ribosomal gene (16S rDNA) gene partial sequencing. The tool proposed here can be used for better directing PHA production based on PHA biosynthesis genes and bacterial genera. Class I or II phaC genes were detected in 9 different genera and were able to infer the type of polymer produced.

Traditional stains such as Sudan black B (Schlegel et al. 1970), Nile blue A (Ostle and Holt, 1982) and Nile red (Spiekermann et al. 1999) have been used for selecting polyhydroxyalcanoate (PHA)-accumulating bacteria. Even though the polymer can be detected in some bacteria in normal growth conditions, PHA production frequently depends on unbalanced nutritional requirements (Madison and Huisman, 1999). These traditional methods are unspecific and laborious; polymerase chain reaction-based (PCR) molecular methods (Sheu et al. 2000; Solaiman et al. 2000; Shamala et al. 2003) have thus become a highly sensitive and precise tool for detecting and amplifying the gene encoding PHA synthase.

PHA biosynthesis genes have been cloned and expressed and their genetic organization has been extensively reported (Madison and Huisman, 1999; Rhem and Steinbüchel, 1999; McCool and Cannon, 2001). PHA synthases (PhaC) are key enzymes in PHA producing polymer granules (Rehm, 2003). These enzymes are classified into four classes according to genetic sequence-deduced primary structure, substrate specificity and subunit composition (Rehm, 2003). PHA structure (short-chain-length (scl) and medium-chain-length (mcl) PHAs) depends on the type of PHA synthase, carbon source and metabolic routes involved (Madison and Huisman, 1999; Rehm and Steinbüchel, 1999).

Polyhydroxyalcanoic acids (PHAs) have been proposed as substitutes for petroleum-derived polymers due to their biodegradable and biocompatible properties. Biosynthesis of scl- or medium-chain-length PHAs (mcl-PHAs) has been widely studied. The present study shows new primers from Class I and II PHA synthase genes which were designed and validated using environmental samples. This work was aimed at selecting native bacteria potentially producing PHA by colony polymerase chain reaction (PCR) amplification of genes encoding Class I and II PHA synthase. An old collection of 55 Gram-negative bacteria, which had been previously selected by phenotype staining methods, plus 34 new strains were evaluated by the PCR method proposed here. The results also led to detecting and differentiating PHA synthase genes, some promising strains being identified by their genetic potential as a source of genes involved in PHA biosynthesis pathways.

\section{MATERIALS AND METHODS}

\section{Bacterial strains and growth conditions}

PHA-positive bacterial strains were used: Ralstonia eutropha American Type Culture Collection (ATCC) 17699, Azospirillum brasilense ATCC 29710, A. amazonense Instituto de Biotecnología, Universidad Nacional de Colombia (IBUN) 87, Azotobacter chroococcum IBUN 88, Aeromonas hydrophyla IBUN 89 and Acinetobacter baumanni IBUN 90 from Class I and Pseudomonas fluorescens IBUN 91, P. putida IBUN 92, P. aeruginosa ATCC 27853 and $P$. aeruginosa IBUN 1040 from Class II. The E. coli XL-1 blue PHA negative strain

Table 1. Characteristics of the environmental samples which were the source of new bacterial isolates.

\begin{tabular}{|c|c|c|c|c|c|c|c|}
\hline Sample No & Type of sample & Department & Rural area & $\begin{array}{l}\text { Geographical } \\
\text { coordinates }^{\text {a }}\end{array}$ & $\begin{array}{l}\text { Height } A^{\mathrm{D}} \\
\text { (m.a s.I.) }\end{array}$ & $\mathrm{pH}^{\mathrm{c}}$ & $\% H^{d}$ \\
\hline 1 & \multirow{3}{*}{$\begin{array}{l}\text { Soil used for adult } \\
\text { sugarcane crop. } \\
\text { Organic agriculture. }\end{array}$} & \multirow{3}{*}{$\begin{array}{c}\text { Cundinamarca } \\
\text { (Villeta) }\end{array}$} & \multirow{2}{*}{$\begin{array}{l}\text { Payandé } \\
\text { (La Luisa) }\end{array}$} & \multirow{2}{*}{$\begin{array}{c}5^{\circ} 00^{\prime} \mathrm{LN} \\
74^{\circ}=30^{\prime} \mathrm{LW}\end{array}$} & \multirow{2}{*}{850} & 6.73 & 34.62 \\
\hline 2 & & & & & & 7.50 & 32.07 \\
\hline 3 & & & $\begin{array}{l}\text { Alto de Torres } \\
\text { (El Paraíso) }\end{array}$ & $\begin{array}{c}4^{\circ}-98^{\prime} \mathrm{LN} \\
74^{\circ}-29^{\prime} \mathrm{LW}\end{array}$ & 1200 & 6.44 & 31.70 \\
\hline 4 & $\begin{array}{c}\text { Marine sludge } \\
(1 \mathrm{~m}, 20 \mathrm{~cm} \text { deep })\end{array}$ & $\begin{array}{c}\text { Bolivar } \\
\text { (Cartagena) }\end{array}$ & $\begin{array}{c}\text { Playa } \\
\text { El Laguito }\end{array}$ & $\begin{array}{l}10^{\circ}-23^{\prime} \mathrm{LN} \\
75^{\circ} 34^{\prime} \mathrm{LW}\end{array}$ & 0 & 7.68 & ND \\
\hline
\end{tabular}

a and b: Data obtained from the Instituto Geográfico Agustín Codazzi (IGAC).

$\mathrm{c}$ and $\mathrm{d}: \mathrm{pH}$ value and gravimetric water content $(\% \mathrm{H})$ were determined according to protocols described by Alef and Nannipieri (1995). ND: Not determined. 
(a)

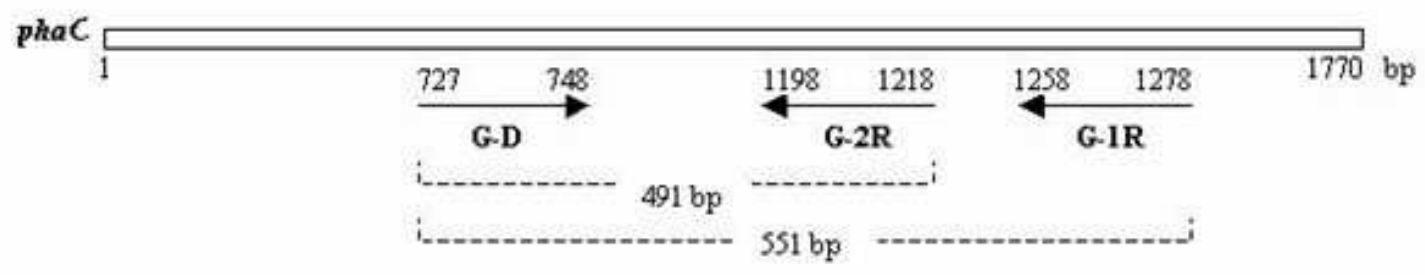

(b)

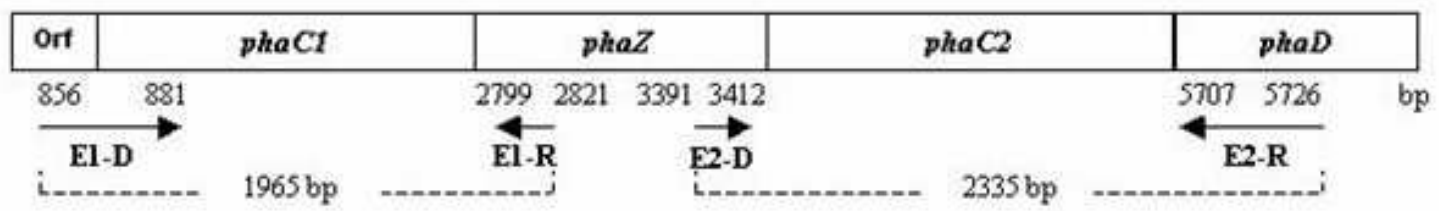

Figure 1. Location of general and specific primers on phaC genes.

(a) General primers on $\boldsymbol{R}$. Eutropha phaC gene. The numbers indicate the positions of the primers on the R. Eutropha phaC gene (GenBank Accession No. J05003) (3'-5'). Dotted lines indicate expected fragment size in colony PCR (G-D and G-1R primers) and seminested PCR (G-D and G-2R primers).

(b) Specific primers on P. aeruginosa Class II PHA synthase byosinthesis genes. 3'-5': ORF, unnamed protein; phaC1 encoding PHA synthase 1; phaC2 encoding PHA synthase 2; phaZ, encoding PHA depolymerase; phaD encoding PhaD (protein having a function in mclPHA biosynthesis). The numbers indicate the positions of the primers in the P. aeruginosa clase II synthase PHA operon sequence (GenBank Accession No. AE004919). Dotted lines indicate the expected fragment size for each pair of primers.

was used as negative control. All control strains were provided by the IBUN. An old collection of 55 bacterial strains was evaluated; this collection was previously selected on phenotype characteristics regarding presumptive polymer accumulation. 49 bacterial strains from different environmental samples (Table 1) were also isolated according to Gomez et al. (1996) and selected using the molecular tool described here. Nutritive agar medium (DIFCO) was used for maintaining the bacteria and incubated for $24 \mathrm{hrs}$ at $30^{\circ} \mathrm{C}$ and $37^{\circ} \mathrm{C}$ in the case of $E$. coli XL-1 blue.

\section{Colony PCR}

Designing general primers. General primers were designed by multiple sequence alignment, amplifying a fragment of the gene encoding Class I and II PHA synthase. phaC (Class I) and phaCl and phaC2 (Class II) gene sequences deposited in GenBank/EMBL/DDBJ databases were analysed using ClustalW software (Thompson et al. 1994). The 28 sequences used belonged to the following species of Gram-negative bacteria, their GenBank accession number being shown in brackets: Acinetobacter sp. (L37761), Aeromonas caviae (D88825), A. hydrophyla (AY093685), R. eutropha (J05003), Alcaligenes latus (AF078795), A. latus (U47026), Alcalingenes sp. (U78047), Azotobacter sp. (J3119748), A. vinelandii (AF267243), Bradiryzobium japonicum (AY077580), Chromobacterium violaceum (AF061446), Methylobacterium extorquens (L07893), Paracoccus denitrificans (D43764), Pseudomonas aeruginosa (AE004919) (phaC1 and phaC2), P. oleovorans (M58445) (phaC1 and phaC2), P. putida (AB085816), P. putida (AY113181) (phaC1 and phaC2), Pseudomonas sp. (AB014757), Pseudomonas sp. (AB014758) (phaCl and phaC2), P. stutzeri (AY278219) (phaC1 and phaC2), Rhizobium etli (U30612), R. meliloti (U17227) and Zooglea ramigera (U66242). Primers designed and selected for this work were: G-D (5'GTGCCGCC(GC)(CT)(AG)(GC)ATCAACAAGT3'),G1R (5'GTTCCAG(AT)ACAG(GC)A(GT)(AG)TCGAA3') and G-2R (5'GTAGTTCCA(GC)A(CT)CAGGTCGTT3') (Figure 1). They were synthesised by MWG-Biotech Inc., Mendenhall, USA.

Optimising PCR conditions. PCR with general primers was optimised using the following components: $1 \mathrm{X}$ buffer, $0.2 \mathrm{mM}$ dNTPs, $0.1 \mu \mathrm{M}$ of each primer, $2.5 \mathrm{mM} \mathrm{MgCl}_{2}$, $0.05 \mathrm{U} / \mu \mathrm{l}$ of Taq DNA polymerase (Promega) and water to complete $25 \mu \mathrm{l}$ reaction. 3\% dimethyl sulphoxide (DMSO) (Sigma) and $20 \mathrm{mM}$ ammonium sulphate $\left[\left(\mathrm{NH}_{4}\right)_{2} \mathrm{SO}_{4}\right]$ were used as reaction additives. Amplification reactions were carried out in an thermocycler (MJ Research, Inc.) using the following programme: 1 cycle of $94^{\circ} \mathrm{C}$ for $10 \mathrm{~min}$, $60^{\circ} \mathrm{C}$ for $2 \mathrm{~min}$ and $72^{\circ} \mathrm{C}$ for $2 \mathrm{~min}$ followed by 40 cycles at $94^{\circ} \mathrm{C}$ for $20,55.5^{\circ} \mathrm{C}$ for $45 \mathrm{sec}$ and $72^{\circ} \mathrm{C}$ for $1 \mathrm{~min}$ and a final cycle at $72^{\circ} \mathrm{C}$ for $5 \mathrm{~min}$. DNA template was obtained as follows: colonies isolated from bacteria grown on solid medium on plates for $12 \mathrm{hrs}$ were suspended in $100 \mu \mathrm{l}$ 
sterilised water until reaching $0.7 \mathrm{OD}_{600}$. The cell suspension was heated at $95^{\circ} \mathrm{C}$ for $10 \mathrm{~min}$ and $2.5 \mu \mathrm{l}$ were used in the reaction.

\section{Designing specific primers}

Specific primers were designed for amplifying and differentiating Class II phaCl and phaC2 genes by aligning and analysing Class II PHA biosynthesis operon sequences belonging to the following bacterial species: Pseudomonas sp. (AC AB014758), P. aureofaciens (AB049413), $P$. aeruginosa (AE004919), P. resinovorans (AF129396), $P$. nitroreducens (AF336849), Burkholderia caryophylli (AF394660), P. pseudoalcaligenes (AY043314), P. putida (AY113181), P. stutzeri (AY278219), P. putida (AY286491), P. oleovorans (M58445) and P. aeruginosa (X66592). Primers designed for amplifying the phaCl gene were

E1-D (5'GGAGCGTCGTAGATGAGTAACAAGAA3') and E1R (5'AGGTTGGCGCCGATGCCGTTGAA3'). The primers designed for amplifying the phaC2 gene were E2-D (5'TGCTGGCCTGGCGCATTCCCAA3') and E2-R (5'AAGTGGTAGTAGAGGTTGCC3') (Figure 1). These were synthesised by MWG-Biotech Inc., Mendenhall, USA.

Optimising PCR conditions. PCR using with specific primers was optimised as follows: 1X buffer (complemented with $20 \mathrm{mM}$ ammonium sulphate), $0.2 \mathrm{mM}$ dNTPs, $0.4 \mu \mathrm{M}$ of each primer, $3.0 \mathrm{mM} \mathrm{MgCl} 2,0.05 \mathrm{U} / \mu \mathrm{l}$ of Taq DNA polymerase (Fermentas) and water to complete up to $25 \mu \mathrm{l}$ of reaction. $2.5 \mu \mathrm{l}$ bacterial lysate were used as DNA template. Reactions were carried out in a thermocycler (MJ Research, Inc.) using the TouchdownPCR strategy (Don et al. 1991). The phaCl gene was amplified as follows: 1 cycle at $94^{\circ} \mathrm{C}$ for $5 \mathrm{~min}$, followed by 14 cycles at $94^{\circ} \mathrm{C}$ for $30 \mathrm{sec}, 65^{\circ} \mathrm{C}$ for $30 \mathrm{sec}$ (reduced by $1^{\circ} \mathrm{C}$ for each 2 cycles) and $72^{\circ} \mathrm{C}$ for $1 \mathrm{~min}$, followed by 20 cycles at $94^{\circ} \mathrm{C}$ for $30 \mathrm{sec}, 59^{\circ} \mathrm{C}$ for $30 \mathrm{sec}$ and $72^{\circ} \mathrm{C}$ for $1 \mathrm{~min}$ and then $72^{\circ} \mathrm{C}$ for $5 \mathrm{~min}$. The phaC2 gene was amplified as follows: 1 cycle at $94^{\circ} \mathrm{C}$ for $5 \mathrm{~min}$, followed by 12 cycles at $94^{\circ} \mathrm{C}$ for $30 \mathrm{sec}, 65^{\circ} \mathrm{C}$ for $30 \mathrm{sec}$ (reduced by $1.5^{\circ} \mathrm{C}$ for each 2 cycles) and $72^{\circ} \mathrm{C}$ for $1 \mathrm{~min}$, followed by 22 cycles at $94^{\circ} \mathrm{C}$ for $30 \mathrm{sec}, 57.5^{\circ} \mathrm{C}$ for $30 \mathrm{sec}$ and $72^{\circ} \mathrm{C}$ for $1 \mathrm{~min}$ and then at $72^{\circ} \mathrm{C}$ for $5 \mathrm{~min}$.

\section{Detecting PCR products}

Electrophoresis on $1 \%(\mathrm{w} / \mathrm{v})$ agarose gels (1X TAE) was used for detecting PCR amplification products. $\lambda$ DNA/Hind III $(0.2 \mu \mathrm{g} / \mu \mathrm{l})$ was used as DNA size marker. Run conditions were 6.5 volts/cm for 2 and half hrs. The gel was stained with a $0.5 \mu \mathrm{g} / \mathrm{ml}$ ethidium bromide solution and amplified DNA fragments were visualised under UV light and recorded with a GelDoc image digitaliser (BioRad).

\section{Validating colony PCR}

PCR specificity was verified by analysing the nucleotide sequence of a DNA fragment having the expected size and amplified with G-D and G-1R primers in native strain S0804 (chosen randomly). PCR sensitivity was determined by cell concentration limit which was also expressed as being the minimum quantity of DNA template required for amplification. P. aureginosa IBUN 1040 (Class II PHA biosynthesis organisation) was cultivated in nutritive broth (Mikrobiologie) up to $0.7 \mathrm{OD}_{600}$. The number of cells per $\mathrm{ml}$ at this optical density (OD) was determined by the platecount method, in triplicate, at different times. One $\mathrm{ml}$ of culture was centrifuged at 2,432 x g for $6 \mathrm{~min}$; the biomass was washed once with sterilised water, suspended in $100 \mu \mathrm{l}$ water and lysed by heating at $95^{\circ} \mathrm{C}$ for $10 \mathrm{~min}$. This bacterial lysate was used as DNA template in increasing volumes $(0.2 \mu \mathrm{l}$ to $5 \mu \mathrm{l})$ for PCR reactions.

Discarding false positives and false negatives. A seminested PCR was optimised using general primers G-D and G-2R (internal) for discarding false positives and false negatives and confirming partial PCR amplification of the phaC gene using G-D and G-R (external) general primers. Semi-nested PCR conditions were as follows: $2 \mu \mathrm{l}$ DNA template from the first phaC gene amplified product were added to this reaction for positive products and $5 \mu \mathrm{l}$ for negative products. Amplification conditions were the same as those optimised with the general primers.

\section{Determining phaC gene presence in native bacterial strains using general primers}

Fifty-five bacterial strains from a collection having presumptve PHA-accumulation ability were screened by the PCR method described here. New bacterial isolates were obtained from different environmental samples (Table 1). $10 \mathrm{~g}$ of soil or $10 \mathrm{ml}$ sea-sludge were enriched in $90 \mathrm{ml}$ of mineral salts medium (MSM), pH 7.0 (Gomez et al. 1996), containing glucose, fructose and saccharose (5 g/l of each one) as carbon source, $3 \mathrm{~g} / \mathrm{l}$ ammonium sulphate as nitrogen source and $0.001 \mathrm{~g} / \mathrm{l}$ crystal violet and $0.03 \mathrm{~g} / \mathrm{l}$ cycloheximide as gram-positive bacteria and fungi inhibitors. $0.1 \mathrm{ml}$ of serial dilutions were spread on solid MSM medium containing $5 \mathrm{~g} / \mathrm{l}$ glucose, fructose or saccharose and incubated at $30^{\circ} \mathrm{C}$ for $24 \mathrm{hrs}$. Colonies having different macroscopic and microscopic morphology were maintained in nutritive agar (DIFCO). Colony PCR was used for directly selecting bacteria having PHAaccumulation ability. The presence of the PHA synthase gene in the bacteria was designated as being phaC+ and its absence as phaC-; phaC+ strains were then cultured on nitrogen-deficient MSM medium plates ( $1 \mathrm{~g} / \mathrm{l}$ ammonium sulphate) for 5 days and PHA granules were visualised by Sudan black B staining (Schlegel et al. 1970).

\section{Partial characterisation of the $16 \mathrm{~S}$ ribosomal gene (16S rDNA)}

Randomly chosen native bacteria from the old and new collections, which had been previously subjected to phaC gene determination, were characterised by partial 
sequencing of the $16 \mathrm{~S}$ rDNA gene. A, E (direct) and $\mathrm{J}$ (reverse) primers (primer J was modified by Montoya et al. 2001) were used for amplifying gene. The amplification reaction used the following mixture: $1 \mathrm{X}$ buffer, $0.18 \mathrm{mM}$ dNTPs, $0.3 \mu \mathrm{M}$ of each primer, $1.5 \mathrm{mM} \mathrm{MgCl}_{2}$ and 0.05 $\mathrm{U} / \mu \mathrm{l}$ of Taq DNA polymerase (Promega) and water up to $25 \mu \mathrm{l} .2 .5 \mu \mathrm{l}$ bacterial lysate were added as DNA template. All PCR reactions were done in a PTC-100 thermocycler (MJ Research, Inc.) in the following conditions: 1 cycle at $94^{\circ} \mathrm{C}$ for $2 \mathrm{~min}, 25$ cycles at $94^{\circ} \mathrm{C}$ for $15 \mathrm{sec}, 62^{\circ} \mathrm{C}$ for 30 sec and $72^{\circ} \mathrm{C}$ for $50 \mathrm{sec}$ and then one cycle at $94^{\circ} \mathrm{C}$ for 15 sec, $62^{\circ} \mathrm{C}$ for $30 \mathrm{sec}$ and $72^{\circ} \mathrm{C}$ for $7 \mathrm{~min}$. PCR products were sequenced by the Macrogen Company (Korea). The search for similarity amongst $16 \mathrm{~S}$ rDNA gene partial sequence from native bacterial strains was done by alignments with sequences from GenBank/EMBL/DDBJ databases using BLAST software (Altschul et al. 1997). Native 16S rDNA gene partial sequences and database reference sequences were aligned using ClustalW program (Thompson et al. 1994); MEGA 3.0 software (Kumar et al. 2004) was used for making a similarity dendogram.

Sequence accession numbers. The $16 \mathrm{~S}$ rDNA gene partial sequences have been deposited in GenBank under accession numbers: DQ813307, DQ813308, DQ813309, DQ813310, DQ813311, DQ813312, DQ813313, DQ813314, DQ813315, DQ813316, DQ813317, DQ813318, DQ813319, DQ813320, DQ813321, DQ813322, DQ813323, DQ813324, DQ813325, DQ813326, DQ813327, DQ813328, DQ813329, DQ813330, DQ813331, DQ813332, DQ813333, DQ813334, DQ813335, DQ813336, DQ813337, DQ813338, DQ813339 and DQ813340. The phaCl gene partial sequence had been deposited in GenBank under accession number DQ826388.

\section{RESULTS}

\section{Amplifyingthe phaC gene fragment}

Three degenerate primers (general) were designed by analysing 28 Class I and II phaC. The so designed G-D and G-1R general primers directly amplified a phaC gene 551 base pairs (bp) fragment in 8 of the bacteria used as positive control corresponding to 5 bacterial genera: Ralstonia, Aeromonas, Azospirillum, Acinetobacter and Pseudomonas. A. amazonense IBUN 87 and $A$. chroococcum IBUN 88 could not be directly detected when G-D and G-1R primers were used. However, semi-nested PCR using G-D and G-2R primers confirmed phaC gene presence (Figure 2). These results confirmed the efficiency of the reaction for amplifying the two types of phaC genes, type I ( $R$. eutropha) and type II ( $P$. aeruginosa), using a G$\mathrm{D}$ and $\mathrm{G}-1 \mathrm{R}$ primers.

\section{Validating colony PCR}

PCR specificity was determined by analysing partial sequence $p h a C$ gene of native bacterial strain IBUN S0804. G-D and GD-1R primers were used for amplifying phaC gene. Theoretically, this should have given $551 \mathrm{bp}$, but 514 bp were obtained. The partial phaC gene sequence (DQ826388) from this strain showed 95\% similarity with the $P$. aureofaciens phaCl gene sequence. PCR sensitivity was defined as being the minimum of viable cells. This limit detection was around $2 \times 10^{4}$ viable cells, corresponding to $345 \mathrm{ng}$ DNA; the best band resolution was obtained with $4 \mu \mathrm{g}$ DNA from $\sim 2.3 \times 10^{5}$ viable cells. Thus, $2.5 \mu \mathrm{l}$ bacterial lysate was used in all subsequent reactions.
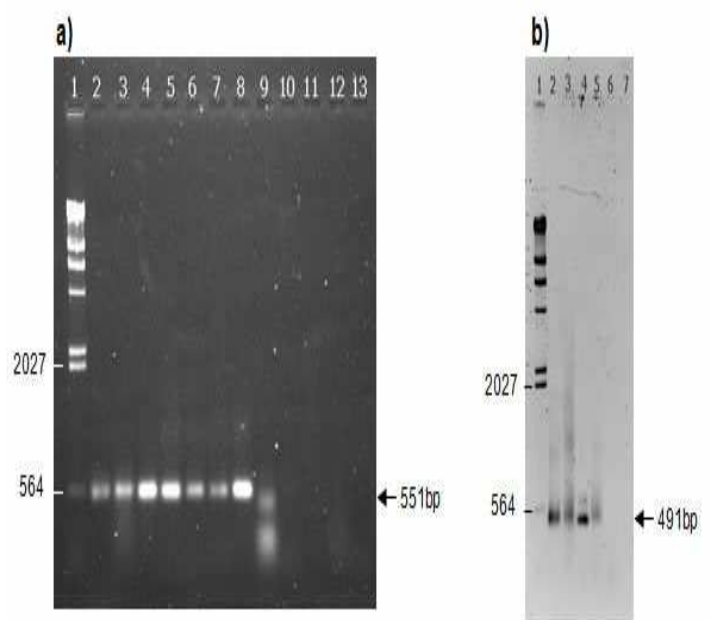

Figure 2. PCR amplification of phaC gene for control strains.

(a) Colony PCR amplification of a phaC gene fragment using G-D and G-1R primers. Lane 1, molecular weight marker $(\lambda$ ADN HindIII); 2, $R$. eutropha ATCC 17699; 3, A. hydrophyla IBUN 89; 4, A. brasilense ATCC 29710; 5, A. baumanni IBUN $90 ; 6$, $P$. aeruginosa IBUN 1040; 7 , P.aeruginosa ATCC 27853; 8, $P$. fluorescens IBUN 91; 9, $P$. putida IBUN 92;10, A. chroococcum IBUN 88; 11, A. amazonense IBUN 87; 12, E. coli XL-1 blue (negative control); 13, reagent control.

(b) Confirmation by semi-nested PCR using G-D and G-2R primers. Lane 1, molecular weight marker ( $\lambda$ ADN HindlII); $2, P$. aeruginosa ATCC 27853 (phaC+); 3, P. putida IBUN 92 (phaC+); 4, A. amazonense IBUN 87; 5 , A. chroococcum IBUN 88; $6, E$. coli XL-1 blue (negative control); 7 , reagent control.

\section{Selecting native PHA-producing isolates by amplifying a phaC gene (Class I and II) fragment and Class II phaC gene differentiation}

Thirty-four of the 55 bacterial isolates belonging to the old collection were phaC+. 16S rDNA characterisation of 18 of these positive strains showed that they belonged to the following genera: Burkholderia, Rhizobium, Pseudomonas andan isolate from the Enterobacteriaceae family. A phaCisolate was included in this analysis and was very similar to Stenotrophomonas maltophilia which has not been reported as being a PHB-producer (Palleroni and Bradbury, 1993). The primers were also able to amplify this gene in other PHA- accumulator bacterial species which are different to the genera represented by the reference strains (Burkholderia, Rhizobium and a genus from the Enterobacteriaceae family). 
(a)

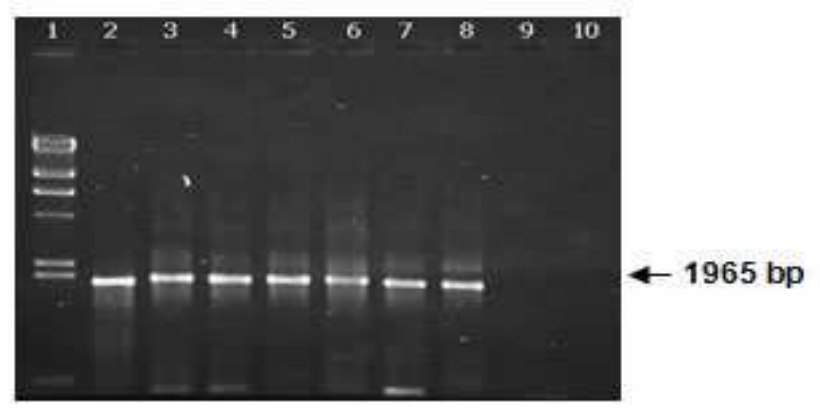

(b)

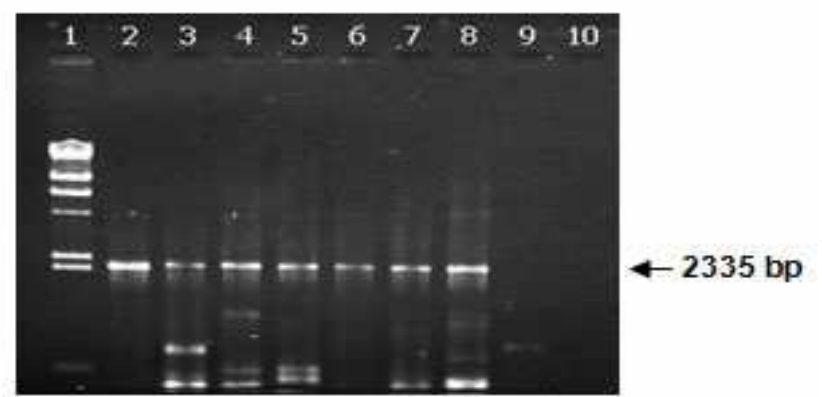

Figure 3. Colony PCR amplification of the phaC1 and phaC2 genes in reference bacteria and native bacteria from the old collection.

(a) Amplifying the phaC1 gene using E1-D and E1-R primers.

(b) Amplifying the phaC2 gene using E2-D and E2-R primers.

Lane 1, molecular weight marker (I ADN HindlII); 2, Pseudomonas fluorescens IBUN 91; 3, Pseudomonas sp. IBUN C14; 4, Pseudomonas sp. IBUN C16; 5, Pseudomonas sp. IBUN S0804; 6, Burkholderia sp. IBUN S1602; 7, Pseudomonas sp. IBUN S1804; 8, Pseudomonas sp. IBUN 1G-3*; 9, E. coli XL-1 Blue (negative control); 10, reagent control.

Thirty-five PHA-producing isolates from the new collection were obtained from soil and sea-sludge samples following colony PCR with G-D, G-1R and G-2R general primers. These phaC+ isolateswere then evaluated regarding their PHA-accumulating ability as described in Materials and Methods. However, polymer granules were also observed by Sudan black B staining (Schlegel et al. 1970) in some isolates strains grown on nutritive agar. Twenty-three isolates accumulated polymer on both culture mediums (9 on MSM medium and 3 on nutritive agar). Regarding the use of carbon sources in MSM medium, 13 accumulated polymer from glucose, fructose and saccharose, 3 from glucose and saccharose, one from glucose and fructose and 6, 4, and 5 from glucose, fructose and saccharose respectively. 16S rDNA characterisation of 16 of these isolates showed that they had high similarity with bacterial species from the Pseudomonas genus.

\section{Differentiating Class II PHA synthase organisation}

Two pairs of specific primers were designed to establish the difference between Class I and Class II PHA synthase. The phaCl gene was amplified by E1-D and E1-R primers and E2-D and E2-R primers amplified the phaC2 gene. Both genes were amplified in $P$. putida IBUN 92 and $P$. fluorescens IBUN 91, in $P$. aeruginosa ATCC 27853 and $P$. aeruginosa IBUN 1040 considered to be a positive control in this study were not amplified. Nine out of 55 isolates from the old bacterial collection were evaluated with the specific primers for determining Class II PHA biosynthesis operon organisation. Native bacterial strains characterised as being Pseudomonas spp. (IBUN C14, IBUN C16, IBUN S0804, IBUN 1G-3*, IBUN S1804 and IBUN S1602) amplified both phaC1 and phaC2 genes
(Figure 3), but IBUN S1407 (Pseudomonas sp.) could not be amplified, nor could IBUN 2G-57 (Burkholderia sp.) or IBUN N3510 (S. maltophilia).

IBUN C14, IBUN C16 and IBUN S1407 strains (Pseudomonas spp.) were preliminarily characterised as having mcl-PHA polymer Class II; this was confirmed by characterising the polymer in the laboratory (results not shown). Native strain IBUN S1602 was similar to species from the Burkholderia genus; this type of organisation is known in the Burkholderia caryophylli specie (Hang et al. 2002). However, native strain IBUN 2G-57 characterised as being Burkholderia sp. and having a PHA preliminarily characterised by sweeping differential calorimetry as PHB (data not shown) only amplified the Class I phaC gene.

\section{Partial 16S rDNA gene sequence análisis}

The 16S rDNA gene partial sequence from some native bacteria was obtained by splicing the $726 \mathrm{bp}$ (amplified with $\mathrm{A}$ and $\mathrm{J}$ primers) and $1420 \mathrm{bp}$ fragments (amplified with $\mathrm{E}$ and $\mathrm{J}$ primers). Most of these bacterial strains (IBUN 1G-3*, IBUN C14, IBUN C16, IBUN C22, IBUN C25, IBUN C29, IBUN N2103, IBUN S1407, IBUN S1601, IBUN S1308, IBUN S1402, IBUN S1804, IBUN S1901, IBUN L41, IBUN P5, IBUN P8B and IBUN MAR1 to IBUN MAR13) were more than $96 \%$ similar to species from the Pseudomonas genus. IBUN N3510 was $99 \%$ similar to the $S$. maltophilia specie and IBUNS1602 had 98\% and 99\% similarity with Burkholderia cepacia ATCC 53795 and Burkholderia sp. CCBAU23014 respectively. IBUN 2G-57 was 98\% more similar to species from the Burkholderia genus, IBUN B69 was 97\% more similar to species from the Rhizobium genusand IBUN N2004 was 
$96 \%$ to $98 \%$ similar with genera from the Enterobacteriaceae family. The native bacteria included here were grouped into 5 clusters (bootstrap presented $100 \%$ confidence values for each cluster) (Figure 4). The distribution of all native pseudomonads was agreed with the classification established by Anzai et al. (2000). Pseudomonas spp. isolated from sea-sludge were grouped with $P$. stutzeri, a specie belonging to the $P$. aeruginosa sub-group of rRNA group I; they could be different nonfluorescent $P$. stutzeri strains, one of the most controversial bacterial species due to its extreme phenotypical diversity covering a heterogeneous set of strains (Lalucat et al. 2006).

Bacterial species from the Enterobacteriaceae family were shown in the second cluster where N2004 was grouped; this seemed to be distanced from $K$. pneumoniae, a bacteria described in this group as being a polymer-accumulator (Wong et al. 2002). The third cluster included $S$. maltophilia (Palleroni and Bradbury, 1993), like IBUN N3510. The fourth cluster included 2G-57, closely related to Burkholderia strain. The close relationship of B69 to species from the Rhizobium genera was observed in the fifth cluster, especially to $R$. etli, however, is necessary to consider other approaches Eardly et al. (2005).

\section{DISCUSSION}

Native PHA-accumulator Gram-negative bacteria were selected by detecting and differentiating genes encoding PHA synthase Class I and II. The great diversity of PHAproducing microorganisms could represent a multiplicity of intra-cell conditions to which PHA synthase had to adapt itself to. This could explain the low level of identity between different PHA synthase sequences (Madison and Huisman, 1999).

The present work, involving designing degenerate primers from nucleotide sequences, led to amplifying the phaC gene (Class I and II) fragment in different bacterial species. The spectra for detecting this gene was broadened by including other sequences deposited to date in GenBank/EMBL/DDBJ databases, in addition to the 13 sequences considered by Sheu et al. (2000). Three bacterial genera were considered (Bradirhizobium, Chromobacterium and Azotobacter) plus another eight species: Azotobacter sp., A. vinelandii, Pseudomonas sp, $P$. stutzeri, $P$. putida, Chromobacterium violaceum, Bradyrhizobium japonicum and A. hydrophyla. Based on the alignment, other regions were analysed which led to designing primers having a 4- to 16-fold degeneracy, thereby favouring specificity.

Analysing the $\mathrm{G}+\mathrm{C}$ content of the 28 sequences used for designing the primers revealed $55 \%$ to $68 \%$ content (except for Azotobacter sp. (51.82\%), Azotobacter vinelandii (51.29\%) and Acinetobacter sp. (41.29\%)). Amplifying GC-rich regions from the phaC gene was optimised in this study by using $3 \%$ DMSO and $20 \mathrm{mM}$ ammonium sulphate as additives (Sambrook and Russell, 2001).

Validating the PCR methodology using amplified phaC gene specificity, sensitivity, efficiency and confirmation parameters conferred the required reliability on the technique for amplifying the phaC gene in different bacterial species. Susceptible measurement detection limit corresponded to $2 \times 10^{4}$ viable cells; it could have been even less, in spite of the degree of primer degeneration and the low purity of the DNA used as template. The three general primers designed in this research amplified a Class I or II phaC gene fragment in Gram-negative bacteria belonging to 9 different genera (including control and native strains) representing PHA synthase Class I and II: Ralstonia, Aeromonas, Azospirillum, Acinetobacter, Azotobacter, Pseudomonas, Burkholderia, Rhizobium and a member of the Enterobacteriaceae family.

Genes adjacent to phaCl and phaC2 genes (Figure 1) were considered in designing the primers for fully differentiating Class I phaC. Solaiman et al. (2000) designed a PCR methodology for detecting phaC1/2 genes but it did not allow differentiating the arrangement of Class II PHA biosynthesis operon genes, since they designed primers for amplifying a fragment from the phaCl and phaC2 genes. The complete open reading frames (ORF) of both genes were also amplified in this work in reference strains and some native strains. The primers designed in this work could be using in cloning strategies as shown in other studies (Zhang et al. 2001). The Touchdown PCR (Don et al. 1991) strategy allowed amplifying the phaCl and phaC2 genes and this led to reducing non-specific amplifications.

Detecting and differentiating phaC genes in native bacteria by colony PCR, combined with the preliminary characterisation by $16 \mathrm{~S}$ rDNA, has proved to be an instrument for the precise and directed selection of bacteria from different genera having the potential for accumulating PHAs. Native strains' genetic potential could be predicted regarding novel PHA production. $P$. aeruginosa ATCC 27853 and $P$. aeruginosa IBUN 1040 Class II PHA synthase genes could not be amplified with the specific primers; it is probable that these genes could have been different to type II (Solaiman et al. 2000).

The isolates from the old IBUN collection had been previously selected by traditional methods and were grown in the necessary conditions for detecting PHA production. The best PHA-producing strains were phaC+, including IBUN 2G-57 (Burkholderia sp.), IBUN B69 (Rhizobium sp.), IBUN C14 (Pseudomonas sp.), IBUN C16 (Pseudomonas sp.), IBUN S1407 (Pseudomonas sp.) 
Romo, D.M.R et al.

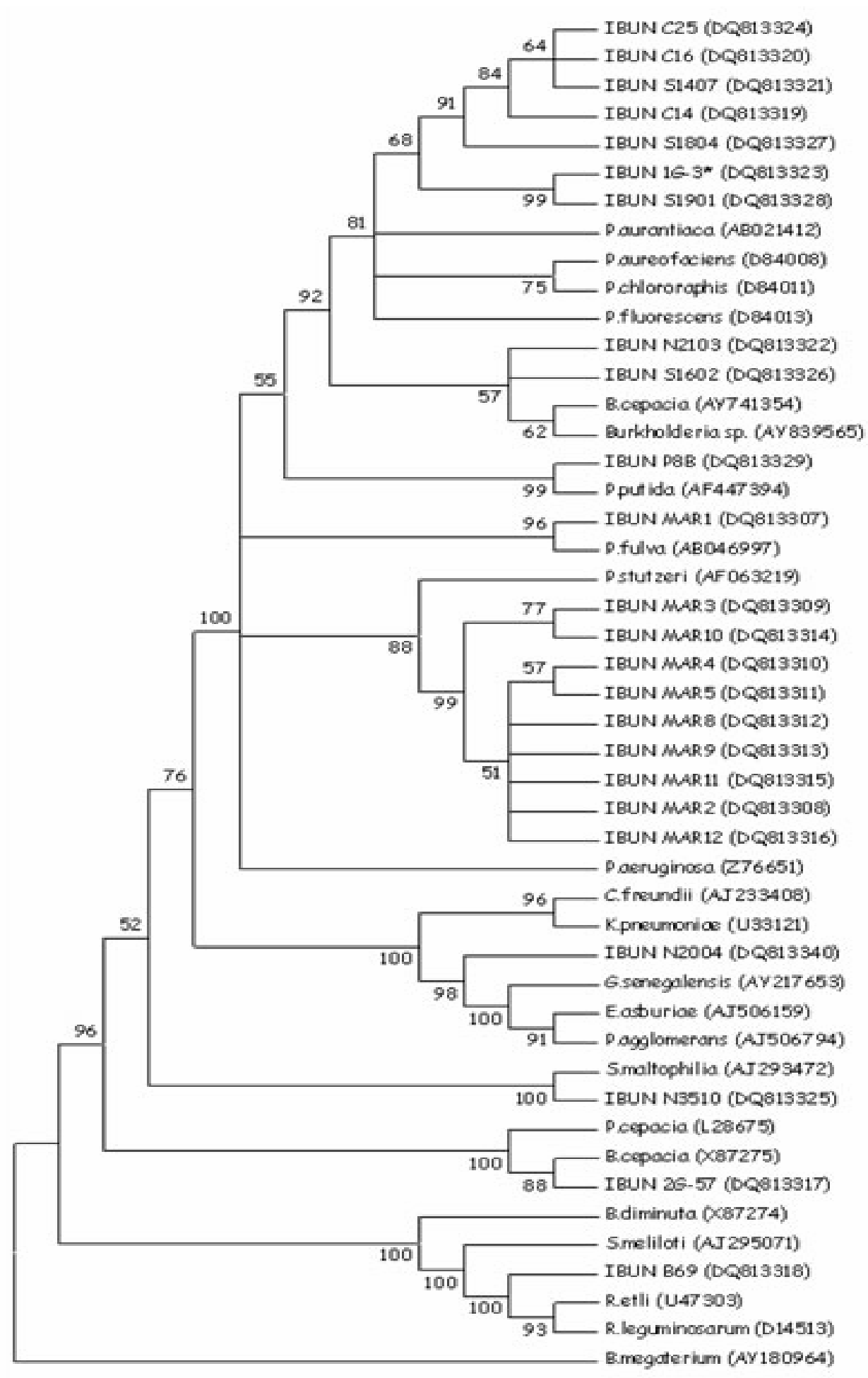

Figure 4. Dendogram of native bacterial strain similarity based on analysing $16 \mathrm{~S}$ ribosomal gene partial sequences.

The dendogram was constructed from the 1,400 to 1,500 bp $16 \mathrm{~S}$ rDNA gene sequences by the Neighbour-joining method using the $\mathrm{P}$ distance with MEGA 3.0 software (Kumar et al. 2004). External group, B. megaterium. The dendogram shows five clusters. The first cluster corresponds to bacteria from the Pseudomonas genera (Anzai et al. 2000). The second cluster, formed by bacterial species from the Enterobacteriaceae family, belonged to IBUN N2004. IBUN N3510 was in the third cluster, similar to S. maltophilia. The fourth cluster contained IBUN 2G-57, closely related to Burkholderia cepacia. The fifth cluster was observed to be closely related to IBUN B69 with species from the genera. 
and IBUN N2004 (Enterobacteriaceae family). Other native strains such as IBUN S1602 related to species from the strains such as IBUN S1602 related to species from the Burkholderia genus could represent reported Class II PHA synthase, this posed the need to confirm its identification using other taxonomic analysis strategies, due to the inference which its classification has relating to PHA biosynthesis genes. Hang et al. (2002) confirmed that species from the Burkholderia genus possessed at least two PHA synthetic pathways having different substrate specificity and cloned the type II system in B. caryophylli AS 1.2741. However, the IBUN N3510 strain ( $S$. maltophilia) from the old collection was phaC-; this result agreed with the description of the genus (Palleroni and Bradbury, 1993) related to poly- $\beta$-hydroxybutyrate granule accumulation.

PHA synthase type II organisation was differentiated in native IBUN C14 and IBUN C16 strains, corroborating preliminary characterisation in previous work regarding the type of polymer produced by these bacteria, corresponding to mcl-PHA, a typical polymer produced by most pseudomonads, especially by species belonging to the I rRNA group (Solaiman et al. 2006). The IBUN S1407 strain also belongs to this group; however, it did not present Class IIPHA synthase organisation. A precise characterisation profile of the polymer produced by IBUN S1407, combined with a study directed towards PHA biosynthesis genes, could lead to reporting the genetic polymer-accumulation system in this bacterial strain.

Different native Pseudomonas spp. characterised in this study showed similarity with Pseudomonas from different groups established by Anzai et al. (2000): the P. chloraphis group, $P$. fluorescens group, $P$. putida group, $P$. stutzeri group and the $P$. aureginosa group (Figure 4). These bacteria thus represent a resource for producing different mcl-PHA from different carbon sources such as fatty acids or carbohydrates (Solaiman et al. 2006). Differentiating the Class II PHA synthase system allows native bacteria having mcl-PHA-accumulating ability to be selected and, eventually, the cloning of PHA biosynthesis genes for constructing more efficient recombinant production systems.

The new collection (containing the thirty-five new phaC+ potentially PHA-accumulating bacteria selected by colony PCR isolated in this study from different environmental samples) was also confirmed by PHA staining. Bacterial strains from sea-sludge constitute a biotechnological source for producing different PHAs. The phaC gene fragment amplified in these strains had a greater size respecting that amplified in $R$. eutropha (results not shown).

The PCR methodology for selecting different PHAaccumulator bacterial genera in this investigation represents a rapid, simple and specific tool for detecting and differentiating type I and II PHA synthase genes, thereby eliminating some disadvantages involved in phenotypical selection using different staining, such as the inability to differentiate between scl-PHA, mcl-PHA and other lipid materials (such as triacylglycerols and waxes) and the fact that staining methods require a prior microorganism culture in conditions allowing the polymer to accumulate. Respecting other molecular methods such as hybridisation, colony PCR is a rapid and equally precise procedure which does not require pure, previously prepared DNA.

\section{ACKNOWLEDGMENTS}

We would like to recognise the support provided by the laboratories at the Instituto de Biotecnología, Universidad Nacional de Colombia (UNAL). We would especially like to thank Lidia Riaño for providing technical support and collaboration and Jason Garry for patiently reading and correction the English manuscript.

\section{REFERENCES}

ALEF, Kassem and NANNIPIERI, Paolo. Methods in applied soil microbiology and biochemistry. London, Academic Press Inc., 1995. 576 p. ISBN 0-12-513840-7.

ANZAI, Yojiro; KIM, Hongik; PARK, Ju-Young; WAKABAYASHI, Hisatsugu and OYAIZU, Hiroshi. Phylogenetic affiliation of the pseudomonads based on $16 \mathrm{~S}$ rRNA sequence. International Journal of Systematic and Evolutionary Microbiology, July 2000, vol. 50, no. 4, p. 1563-1589.

ALTSCHUL, Stephen F.; MADDEN, Thomas L.; SCHÄFFER, Alejandro A.; ZHANG, Jinghui; ZHANG, Zheng; MILLER, Webb and LIPMAN, David J. Gapped BLAST and PSI-BLAST: a new generation of protein database search programs. Nucleic Acids Research, July 1997, vol. 25 , no. 17 , p. 3389-3402.

DON, R.H.; COX, P.T.; WAINWRIGHT, B.J.; BAKER, K. and MATTICK, J.S. "Touchdown" PCR to circumvent spurious priming during gene amplification. Nucleic Acids Research, July 1991, vol. 19, no. 14, p. 4008.

EARDLY, B.D.; NOUR, S.M.; VAN BERKUM, P. and SELANDER, R.K. Rhizobial 16S rRNA and dnaK genes: mosaicism and the uncertain phylogenetic placement of Rhizobium galegae. Applied and Environmental Microbiology, March 2005, vol. 71, no. 3, p. 1328-1335.

GOMEZ, J.G.C.; RODRIGUES, M.F.A.; ALLI, R.C.P.; TORRES, B.B.; BUENO NETTO, C.L.; OLIVEIRA, M.S. and DA SILVA, L.F. Evaluation of soil gram-negative bacteria yielding polyhydroxyalkanoic acids from carbohydrates and propionic acid. Applied Microbiology and Biotechnology, July 1996, vol. 45, no. 6, p. 785-791. 
HANG, Xiaoming; ZHANG, Guang; WANG, Guanlin; ZHAO, Xianghui and CHEN, Guo-Qiang. PCR cloning of polyhydroxyalkanoate biosynthesis genes from Burkholderia caryophylli and their functional expression in recombinant Escherichia coli. FEMS Microbiology Letters, April 2002, vol. 210, no. 1, p. 49-54.

KUMAR, Sudhir; TAMURA, Koichiro and NEI, Masatoshi. MEGA 3.0: Integrated software of molecular evolutionary genetics analysis and sequence alignment. Briefings in Bioinformatics, June 2004, vol. 5, no. 2, p. 150-163.

LALUCAT, Jorge; BENNASAR, Antonio; BOSCH, Rafael; GARCÍA-VALDÉS, Elena and PALLERONI, Norberto J. Biology of Pseudomonas stutzeri. Microbiology and Molecular Biology Reviews, June 2006, vol. 70, no. 2, p. 510-547.

MADISON, Lara L. and HUISMAN, Gjalt W. Metabolic engineering of poly(3-hydroxyalcanoates): From DNA to plastic. Microbiology and Molecular Biology Reviews, March 1999, vol. 63, no. 1, p. 21-53.

MCCOOL, Gabriel J. and CANNON, Maura C. PhaC and PhaR are required for polyhydroxyalkanoic acid synthase activity in Bacillus megaterium. Journal of Bacteriology, July 2001, vol. 183, no. 14, p. 4235-4243.

MONTOYA, Dolly; ARÉVALO, Catalina; GONZALES, Sonny; ARISTIZÁBAL, Fabio and SCHWARZ, Wolfgang. New solvent-producing Clostridium sp. strains, hydrolyzing a wide range of polysaccharides, are closely related to Clostridium butyricum. Journal of Industrial Microbiology and Biotechnology, November 2001, vol. 27, no. 5, p. 329335 .

OSTLE, A.G. and HOLT, J.G. Nile blue A as a fluorescent stain for poly- $\beta$-hydroxybutyrate. Applied and Environmental Microbiology, July 1982, vol. 44, no. 1, p. 238-241.

PALLERONI, Norberto J. and BRADBURY, John F. Stenotrophomonas, a new bacterial genus for Xanthomonas maltophilia (Hugh 1980) Swings et al. 1983. International Journal of Systematic Bacteriology, July 1993, vol. 43, no. 3, p. 606-609.

REHM, Bernd H.A. and STEINBÜCHEL, Alexander. Biochemical and genetic analysis of PHA synthases and other proteins required for PHA synthesis. International Journal of Biological Macromolecules, June 1999, vol. 25, no. 1-3, p. 3-19.

REHM, Bernd H.A. Polyester synthases: natural catalysts for plastics. Biochemical Journal, November 2003, vol. 376 , no. 1 , p. 15-33.

SAMBROOK, Joseph and RUSSELL, David W. Molecular cloning: a laboratory manual. $3^{\text {rd }}$ ed. New York; Cold Spring Harbor Laboratory Press, 2001. 999 p. ISBN 087969-576-5.

SCHLEGEL, Hans-Günter; LAFFERTY, Robert and KRAUSS, Isolde. The isolation of mutants not accumulating poly- $\beta$-hydroxybutiric acid. Archives of Microbiology, September 1970, vol. 71, no. 3, p. 283-294.

SHAMALA, T.R.; CHANDRASHEKAR, A.; VIJAYENDA, S.V.N. and KSHAMA, L. Identification of polyhydroxyalkanoate (PHA)-producing Bacillus spp. using the polymerase chain reaction (PCR). Journal of Applied Microbiology, March 2003, vol. 94, no. 3, p. 369374 .

SHEU, Der-Shyan; WANG, Yun-Ting and LEE, Chia-Yin. Rapid detection of polyhydroxyalkanoate accumulating bacteria isolated from the environment by colony PCR. Microbiology, August 2000, vol. 146, no. 8, p. 2019-2025.

SOLAIMAN, Daniel K.Y.; ASHBY, Richard D.; FOGLIA, Thomas A. and MARMER, William N. Conversion of agricultural feedstock and coproducts into poly(hydroxyalkanoates). Applied Microbiology and Biotechnology, August 2006, vol. 71, no. 6, p. 783-789.

SOLAIMAN, Daniel K.Y.; ASHBY, Richard D. and FOGLIA, Thomas A. Rapid and specific identification of medium-chain-length polyhydroxyalkanoate synthase gene by polymerase chain reaction. Applied Microbiology and Biotechnology, June 2000, vol. 53, no. 6, p. 690-694.

SPIEKERMANN, Patricia; REHM, Bernd H.A.; KALSCHEUER, Rainer; BAUMEISTER, Dirk and STEINBÜCHEL, Alexander. A sensitive, viable-colony staining method using Nile red for direct screening of bacteria that accumulate polyhydroxyalckanoic acids and other lipid sotorage compounds. Archives of Microbiology, January 1999 , vol. 171 , no. 2, p. 73-80.

THOMPSON, Julie D.; HIGGINS, Desmond G. and GIBSON, Toby J. CLUSTAL W: improving the sensitivity of progressive multiple sequence alignment through sequence weighting, position-specific gap penalties and weight matrix choice. Nucleic Acids Research, November 1994, vol. 22, no. 22, p. 4673-4680.

WONG, Phoeby A.L.; CHUA, Hong; LO, Waihung; LAWFORD, Hugh G. and YU, Peter H. Production of specific copolymers of polyhydroxyalkanoates from industrial waste. Applied Biochemistry and Biotechnology Part A: Enzyme Engineering and Biotechnology, 2002, vol. 98 , no. $1-9$, p. 655-662.

ZHANG, Guang; HANG, Xiaoming; GREEN, Phillip; HO, Kwok-Ping and CHEN, Guo-Qiang. PCR cloning of type II polyhydroxyalkanoate biosynthesis genes from two Pseudomonas strains. FEMS Microbiology Letters, May 2001, vol. 198, no. 2, p. 165-170. 